Research Paper

\title{
Association of D-dimer elevation with inflammation and organ dysfunction in ICU patients with COVID-19 in Wuhan, China: a retrospective observational study
}

\author{
Wang Zhang ${ }^{1, *}$, Ling Sang ${ }^{2,}{ }^{*}$, Jiaran Shi ${ }^{3, *}$, Ming Zhong ${ }^{4}$, Li Jiang ${ }^{5}$, Bin Song ${ }^{6}$, Liang Kang ${ }^{7}$, Yun \\ Zhang $^{8}$, Dingyu Zhang ${ }^{9,10}$, Yunsong $\mathrm{Yu}^{1}$, Xia Zheng ${ }^{8}$ \\ ${ }^{1}$ Department of Infectious Diseases, Sir Run Run Shaw Hospital, College of Medicine, Zhejiang University, \\ Hangzhou, Zhejiang, P.R. China \\ ${ }^{2}$ Department of Critical Care Medicine, The First Affiliated Hospital of Guangzhou Medical University, Guangzhou \\ Institute of Respiratory Health, Guangzhou, Guangdong, P.R. China \\ ${ }^{3}$ Department of Cardiology, The First Affiliated Hospital, College of Medicine, Zhejiang University, Hangzhou, \\ Zhejiang, P.R. China \\ ${ }^{4}$ Department of Critical Care Medicine, Zhongshan Hospital, Fudan University, Shanghai, P.R. China \\ ${ }^{5}$ Department of Critical Care Medicine, Xuanwu Hospital, Capital Medical University, Beijing, P.R. China \\ ${ }^{6}$ Department of Tuberculosis and Respiratory Disease, Jinyintan Hospital, Wuhan, Hubei, P.R. China \\ ${ }^{7}$ Department of Critical Care Medicine, Jinyintan Hospital, Wuhan, Hubei, P.R. China \\ ${ }^{8}$ Department of Critical Care Medicine, The First Affiliated Hospital, College of Medicine, Zhejiang University, \\ Hangzhou, Zhejiang, P.R. China \\ ${ }^{9}$ Joint Laboratory of Infectious Diseases and Health, Wuhan Institute of Virology and Wuhan Jinyintan Hospital, \\ Chinese Academy of Sciences, Hubei, P.R. China \\ ${ }^{10}$ Research Center for Translational Medicine, Wuhan Jinyintan Hospital, Hubei, P.R. China \\ *Equal contribution
}

Correspondence to: Xia Zheng, Yunsong Yu, Dingyu Zhang; email: zxicu@zju.edu.cn; yvys119@zju.edu.cn; 1813886398@qq.com, https://orcid.org/0000-0002-9277-5705

Keywords: coronavirus disease 2019, COVID-19, critical care, D-dimer, organ dysfunction, retrospective study Received: August 10, $2020 \quad$ Accepted: December 19, $2020 \quad$ Published: February 11, 2021

Copyright: (C) 2021 Zhang et al. This is an open access article distributed under the terms of the Creative Commons Attribution License (CC BY 3.0), which permits unrestricted use, distribution, and reproduction in any medium, provided the original author and source are credited.

\section{ABSTRACT}

Coronavirus disease 2019 (COVID-19)-associated coagulation dysfunction is gaining attention. In particular, dynamic changes in the D-dimer level may be related to disease progression. Here, we explored whether elevated D-dimer level was related to multiple organ failure and a higher risk of death. This study included 158 patients with COVID-19 who were admitted to the intensive care unit (ICU) at Jinyintan Hospital in Wuhan, China between January 20, 2020 and February 26, 2020. Clinical and laboratory data were collected. The relationship between D-dimer elevation and organ dysfunction was analyzed, as were dynamic changes in inflammation and lipid metabolism. Approximately $63.9 \%$ of patients with COVID-19 had an elevated D-dimer level on ICU admission. The 14 day ICU mortality rate was significantly higher in patients with a high D-dimer level than in those with a normal D-dimer level. Patients with a D-dimer level of $10-40 \mu \mathrm{g} / \mathrm{mL}$ had similar organ function on ICU admission to those with a D-dimer level of $1.5-10 \mu \mathrm{g} / \mathrm{mL}$. However, patients with higher levels of D-dimer developed organ injuries within 7 days. Furthermore, significant differences in inflammation and lipid metabolism markers were observed between the two groups. In conclusion, the D-dimer level is closely related to COVID-19 severity and might influence the likelihood of rapid onset of organ injury after admission. 


\section{INTRODUCTION}

Coronavirus disease 2019 (COVID-19), caused by severe acute respiratory syndrome coronavirus 2 , is a considerable threat to public health worldwide. There is increasing evidence that patients with COVID-19 have coagulation dysfunction. In particular, many patients with severe or critical COVID-19 exhibit abnormal coagulation, similar to the systemic coagulopathy associated with severe infection [1], and abnormal coagulation markers are associated with poor prognosis in patients with COVID-19 [2]. Some studies have shown that anticoagulation therapy may improve the prognosis of patients with COVID-19 [3, 4]. However, many such patients (especially those treated in the intensive care unit [ICU]) develop life-threatening thrombotic complications [5].

Thrombotic events frequently occur in patients with COVID-19. Histopathological examination of these patients has revealed a severe pulmonary endothelial injury with widespread thrombosis and microangiopathy, and the rate of the associated alveolar capillary thrombosis is nine fold greater than that of patients with influenza [6]. In addition, multiple histopathological studies have reported thrombosis in extrapulmonary organs, such as the liver and kidneys $[7,8]$. There is a need for laboratory and imaging studies to more comprehensively investigate the coagulation complications of COVID-19, including the treatment thereof, and the usefulness of strict thrombosis prophylaxis.

Elevated D-dimer and fibrin degradation product levels, combined with a prolonged prothrombin time, are the most typical finding in patients with COVID-19 and associated coagulopathy [9]. Notably, elevated D-dimer and fibrin degradation product levels are especially common in patients with fatal disease [2]. A study in China showed increasing risk of in-hospital death with a D-dimer elevation [10]. Furthermore, dynamic observation of the D-dimer level has been used to predict the progression of COVID-19 [11]. However, it is unclear whether the D-dimer levels is directly related to multiple organ failure, or whether it is associated with changes in inflammation and metabolism. Here, we assessed the correlations between D-dimer level on ICU admission and hospital mortality, progression of organ injuries, and dynamic changes in inflammation.

\section{RESULTS}

\section{Demographic and clinical characteristics}

In total, 158 patients with severe or critical COVID-19 were included in this study. The median age of the patients was 62 years (interquartile range: $56-70$ years) and 91 patients $(57.6 \%)$ were men. Seventy-seven patients $(48.7 \%)$ died during treatment in the ICU. Forty-nine patients $(31.0 \%)$ received anticoagulant therapy and $102(64.5 \%)$ received mechanical ventilation [68 $(43.0 \%)$ received noninvasive ventilation and $81(51.3 \%)$ received invasive ventilation] (Table 1$)$.

\section{D-dimer level on ICU admission was correlated with laboratory test results}

The 158 patients were divided into four groups based on their D-dimer level at the time of ICU admission. The D0 group comprised patients with a normal D-dimer level (Ddimer $<1.5 \mu \mathrm{g} / \mathrm{mL}$ ). The D1-D3 groups comprised patients with an abnormal D-dimer level, as follows: D1 $(1.5 \leq \mathrm{D}$ dimer $<10 \mu \mathrm{g} / \mathrm{mL}$ ), D2 (10 $\leq \mathrm{D}$-dimer $<40 \mu \mathrm{g} / \mathrm{mL})$ and D3 (Ddimer $\geq 40 \mu \mathrm{g} / \mathrm{mL}$ ). The laboratory test results were divided into three categories (abbreviations and ranges of normal values are shown in Supplementary Table 3): high (above normal range), normal (within normal range), and low (below normal range). Heat maps were used to show the numbers of patients in the various laboratory test result categories by D-dimer level (Figure 1). At the time of ICU admission, the number of patients with abnormalities in 46 parameters varied by D-dimer level (Figure 1A). During ICU treatment, the number of patients with abnormalities in 52 parameters varied by D-dimer level (Figure 1B). These parameters reflected coagulation function, inflammation level, liver function, renal function, lipid metabolism and myocardial injury. Furthermore, the values of these parameters significantly differed among the four D-dimer groups (Table 1). We evaluated the correlations between D-dimer level and other laboratory test results. The D-dimer level was positively correlated with the white blood cell count (WBC, $\mathrm{r}=0.523, \mathrm{P}<$ 0.001), neutrophil count $(\mathrm{r}=0.557, \mathrm{P}<0.001)$, CRP level $(\mathrm{r}=0.441, \mathrm{P}<0.001)$, procalcitonin level $(\mathrm{r}=$ $0.357, \mathrm{P}<0.001)$, hypersensitive sensitive troponin I level $(\mathrm{r}=0.562, \mathrm{P}<0.001)$, lactate dehydrogenase level $(\mathrm{r}=0.633, \mathrm{P}<0.001)$ and $\alpha$-Hydroxybutyrate dehydrogenase level $(r=0.654, P<0.001)$ for all 158 patients on the first day after ICU admission. On that day, the Ddimer level was negatively correlated with the lymphocyte count $(\mathrm{r}=-0.419, \mathrm{P}<0.001)$ and albumin level $(r=-0.524, \mathrm{P}<0.001)$ (Supplementary Table 1$)$. The results of multivariate Cox regression analysis showed increasing odds of in-ICU death with older age, a higher SOFA score, and higher D-dimer, lactate dehydrogenase, apolipoprotein A, and apolipoprotein B levels on ICU admission (Supplementary Table 2).

\section{D-dimer level on ICU admission was associated with 7- and 14-day mortality rates}

There were no significant differences in the 7-day mortality rate among the D1, D2, and D3 groups. 
Table 1. Characteristics of the study participants with different level of D-dimer.

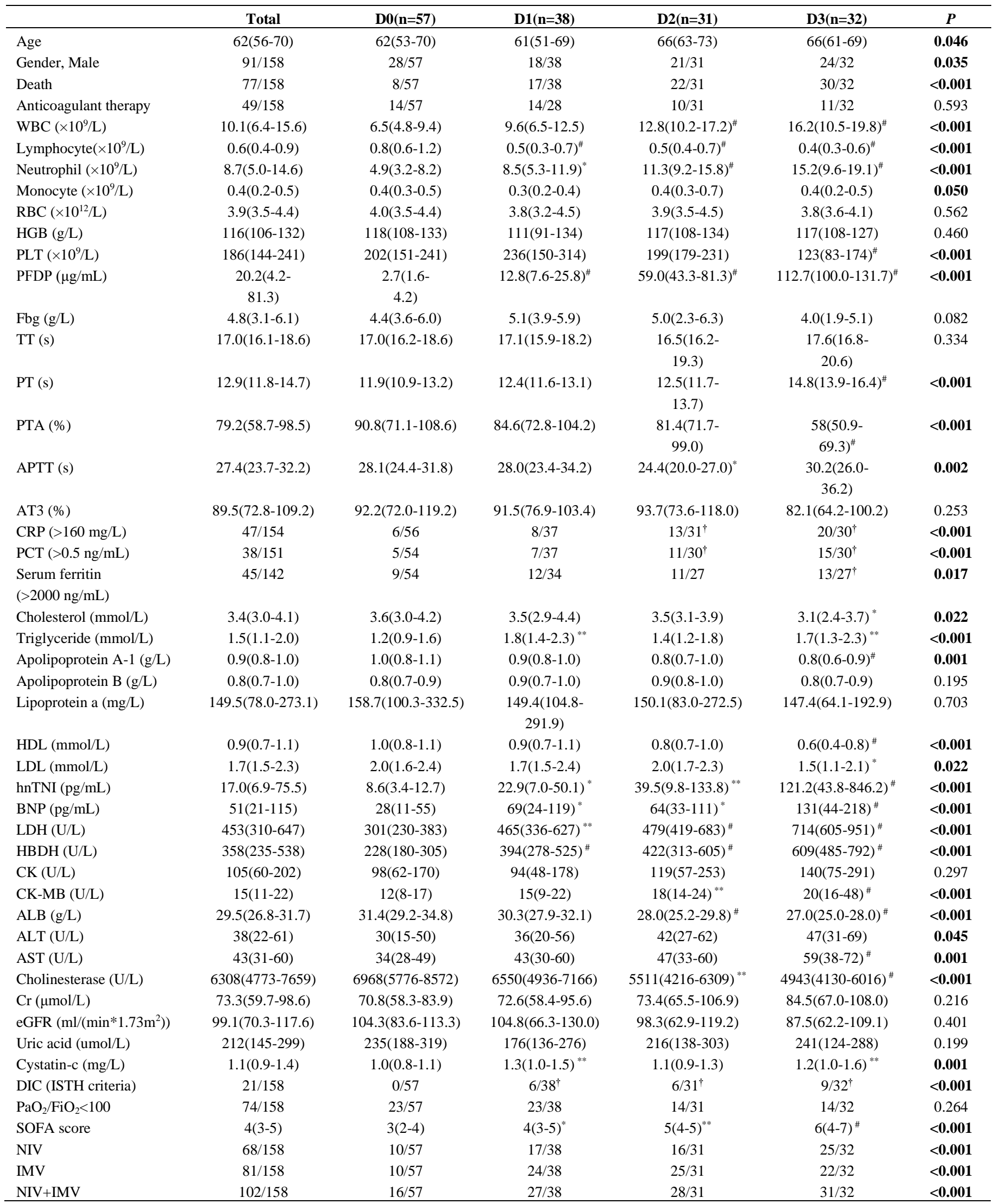

Compared with D0 group, ${ }^{*}<0.05 ;{ }^{* *}<0.01 ; \#<0.001$. + means $\mathrm{P}<0.05$ after adjusting by Bonferroni way. 

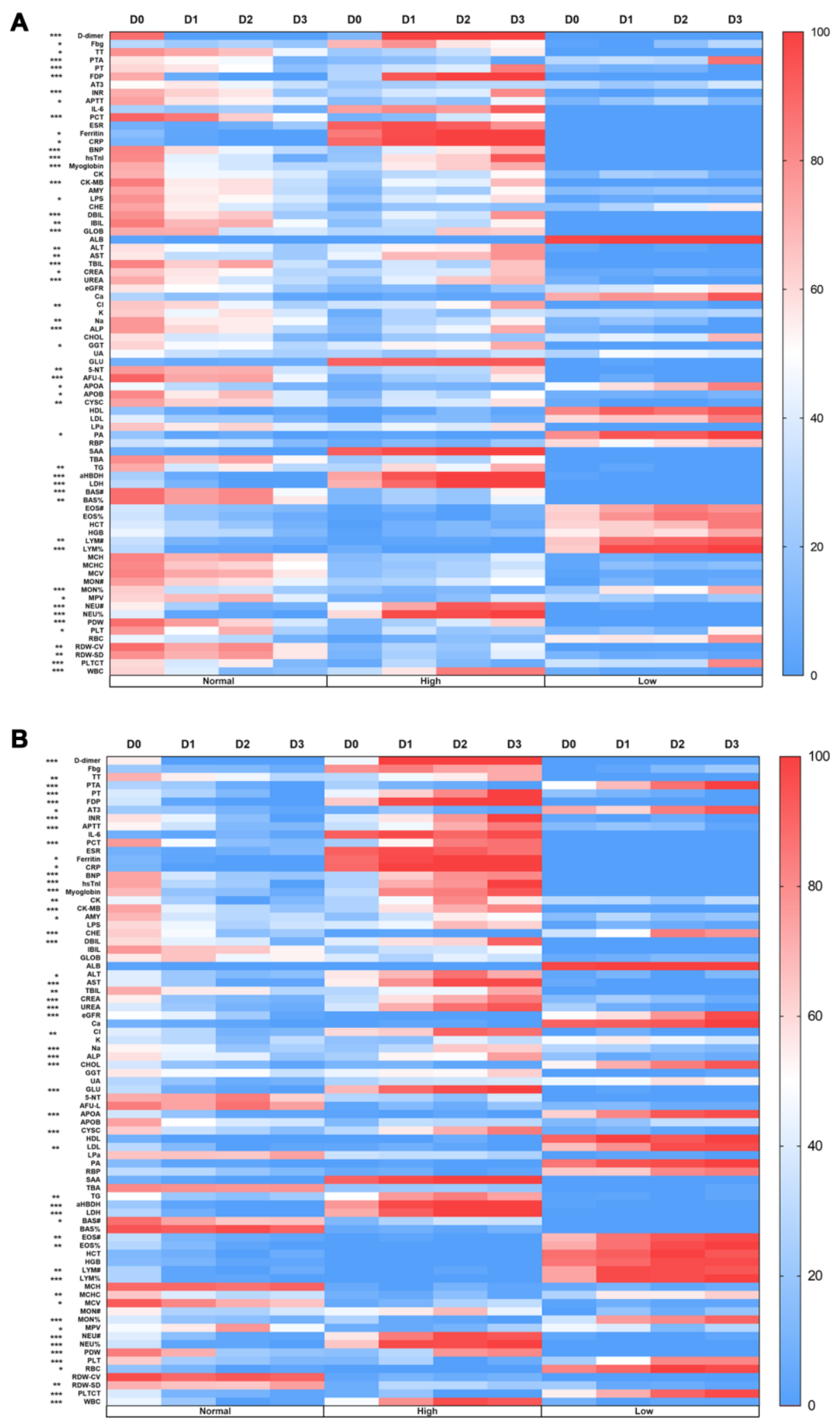

Figure 1. Heat maps of the correlation between the D-dimer level and laboratory results. (A) The number of patients with abnormalities in 46 parameters varied according to D-dimer level at the time of ICU admission. (B) The number of patients with abnormalities in 52 parameters varied according to D-dimer level during ICU treatment. D0: D-dimer $<1.5 \mu \mathrm{g} / \mathrm{mL}, \mathrm{D} 1: 1.5 \leq \mathrm{D}-\mathrm{dimer}<10 \mu \mathrm{g} / \mathrm{mL}, \mathrm{D} 2: 10 \leq \mathrm{D}$ dimer $<40 \mu \mathrm{g} / \mathrm{mL}$, D3: D-dimer $\geq 40 \mu \mathrm{g} / \mathrm{mL}$. Normal: the result is within the normal range, High: the result is beyond the normal range, Low: the result is below the normal range. ${ }^{*} \mathrm{P}<0.05,{ }^{*} \mathrm{P}<0.01,{ }^{* *} \mathrm{P}<0.001$ among these 4 groups, abbreviation and range of normal values can be found in Supplementary Table 3, Supplementary files. 
Within 14 days after ICU admission, the death rates were as follows: D0 group, 5 of 57 patients, $13.66 \%$; D1 group, 14 of 38 patients, 43.57\%; D2 group, 21 of 31 patients, 76.12\%; and D3 group, 23 of 32 patients,74.84\% (Figure 2, Supplementary Figure 2). The 14-day mortality rate was significantly lower in the D0 group than the D1, D2, and D3 groups (all $\mathrm{P}<0.01$ ), and significantly lower in the D1 group than in the D2 and $\mathrm{D} 3$ groups (all $\mathrm{P}<0.05$ ). However, there was no significant difference in the 14 day mortality rate between the D2 and D3 groups ( $\mathrm{p}=0.963$ ) (Figure 2). In addition, there was no significant difference in the ICU mortality rate between male and female patients (Supplementary Figure 1).

\section{D-dimer level on ICU admission was associated with dynamic changes in organ function during ICU treatment}

Organ dysfunction was related to the D-dimer level at the time of ICU admission: in the D3 group, 16 of 32 patients $(50 \%)$ had abnormal liver function, 5 of 32 $(15.63 \%)$ had abnormal renal function, 29 of 32 (90.63\%) had myocardial injury, 11 of $32(34.38 \%)$ had thrombocytopenia. 26 of $32(81.25 \%)$ had severe ARDS and 9 of 32 (28.13\%) had DIC. There was no significant difference in organ function status between the D1 and D2 groups at the time of ICU admission (Figure 3). However, patients in the D2 group experienced rapid deterioration of organ function after ICU admission (Figure 3C-3F). In particular, significantly more patients in the D2 group had thrombocytopenia and DIC, compared with the D1 group, within 4-7 days after ICU admission (Figure 3E, 3F). Additionally, significantly more patients in the D2 group had severe ARDS, compared with the D1 group, within 8-14 days after ICU admission (Figure 3D). Notably, by day 14 after ICU admission, the numbers of patients with liver injury, kidney injury, severe ARDS and DIC were similar between the D2 and D3 groups (Figure 3A, 3B, 3D-3F).

Further analysis of the numbers of patients with organ dysfunction over time showed that the growth rates of the numbers of patients with liver injury, myocardial injury, severe ARDS and DIC peaked at 1-3 days after ICU admission (Figure 4A, 4C-4F), while the growth rates of the numbers of patients with kidney injury and thrombocytopenia peaked at 4-7 days after ICU admission (Figure 4B, 4E). Importantly, within 7 days after ICU admission, the growth rates of the numbers of patients with organ dysfunction was higher in the D2 group than in the other three groups (Figure 4).

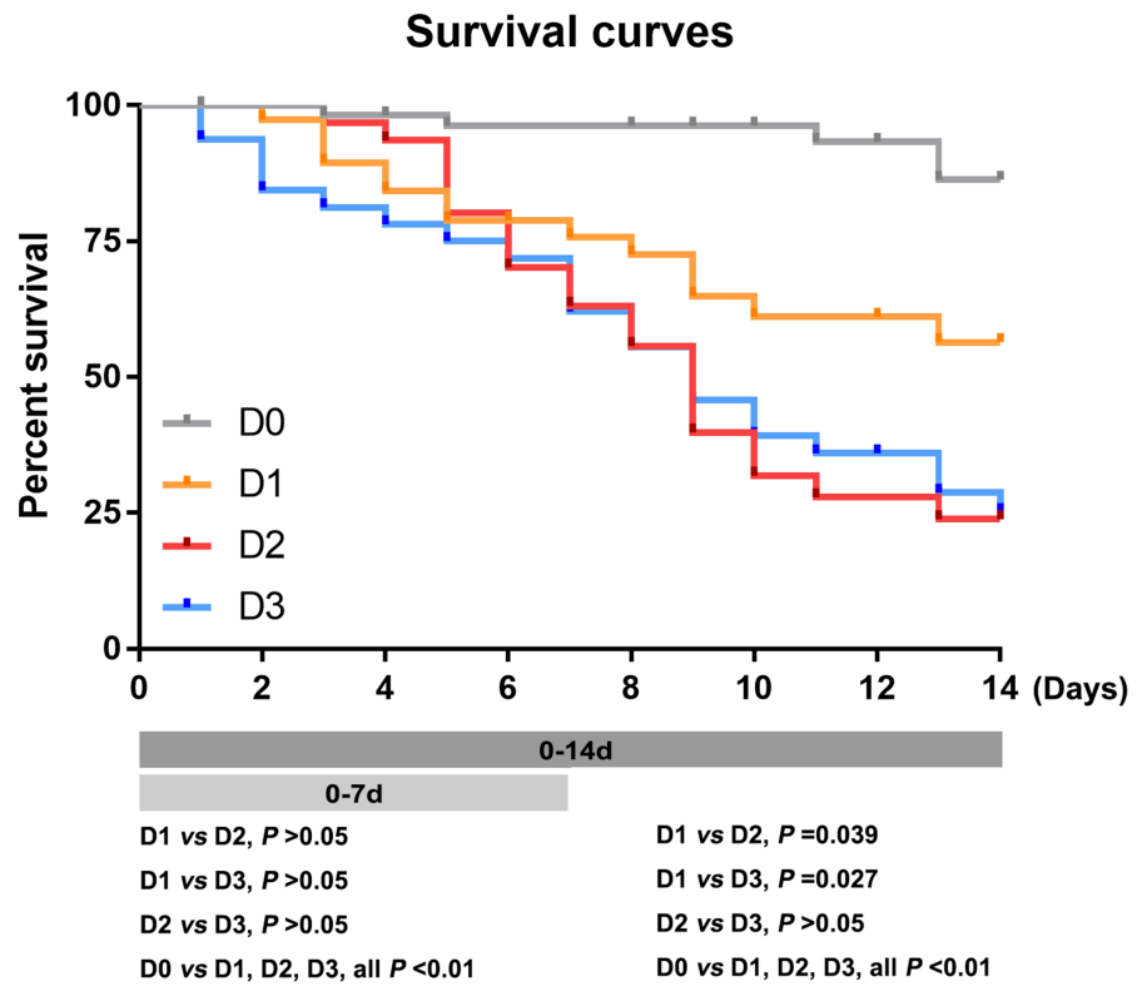

Figure 2. The 7- and 14-day mortality rates in patients with different D-dimer levels at ICU admission. Survival curves of patients

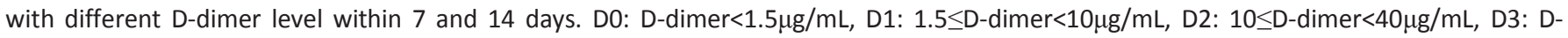
dimer $\geq 40 \mu \mathrm{g} / \mathrm{mL}$. 
Dynamic relationships of inflammation and lipid metabolism markers with D-dimer level

To investigate the causes of rapid progression of organ dysfunction in the patients in the D2 group, we compared the dynamic changes in SOFA score, inflammation status and whole blood cells between the D1 and D2 group patients within 7 days after ICU admission. The results showed that the SOFA score was significantly higher in patients in the D2 group than in those in the D1 group, both 1-3 and 4-7days after ICU admission (Figure 5A). With the exception of neutrophil
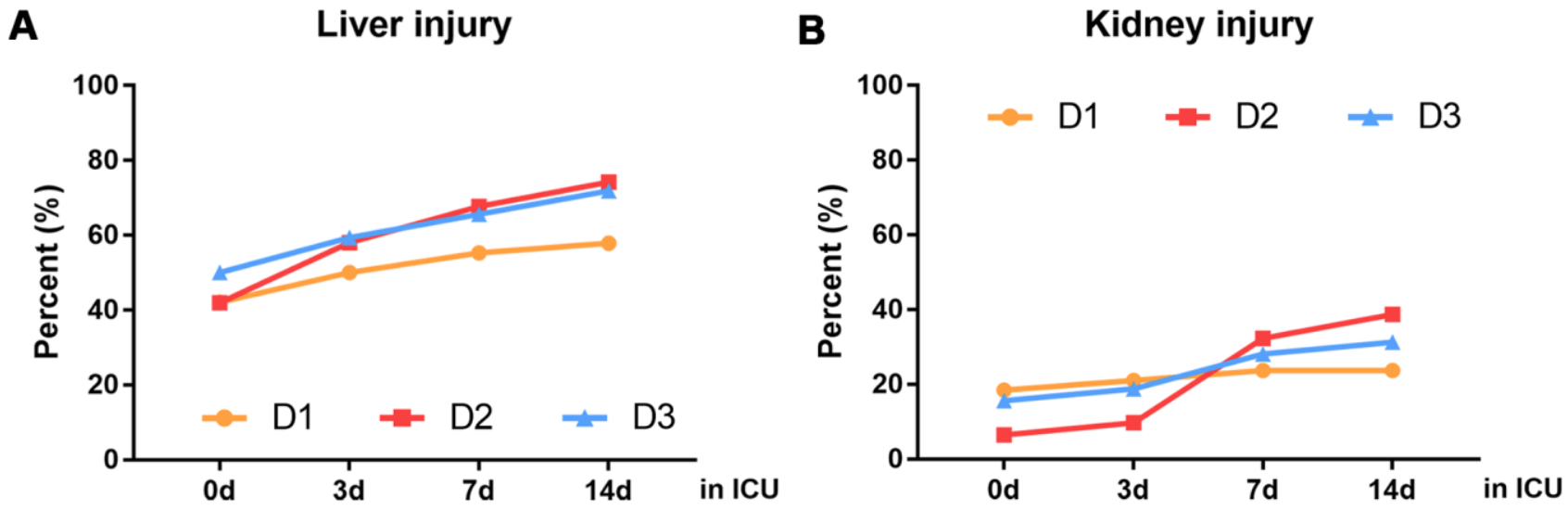

C Myocardial injury

D
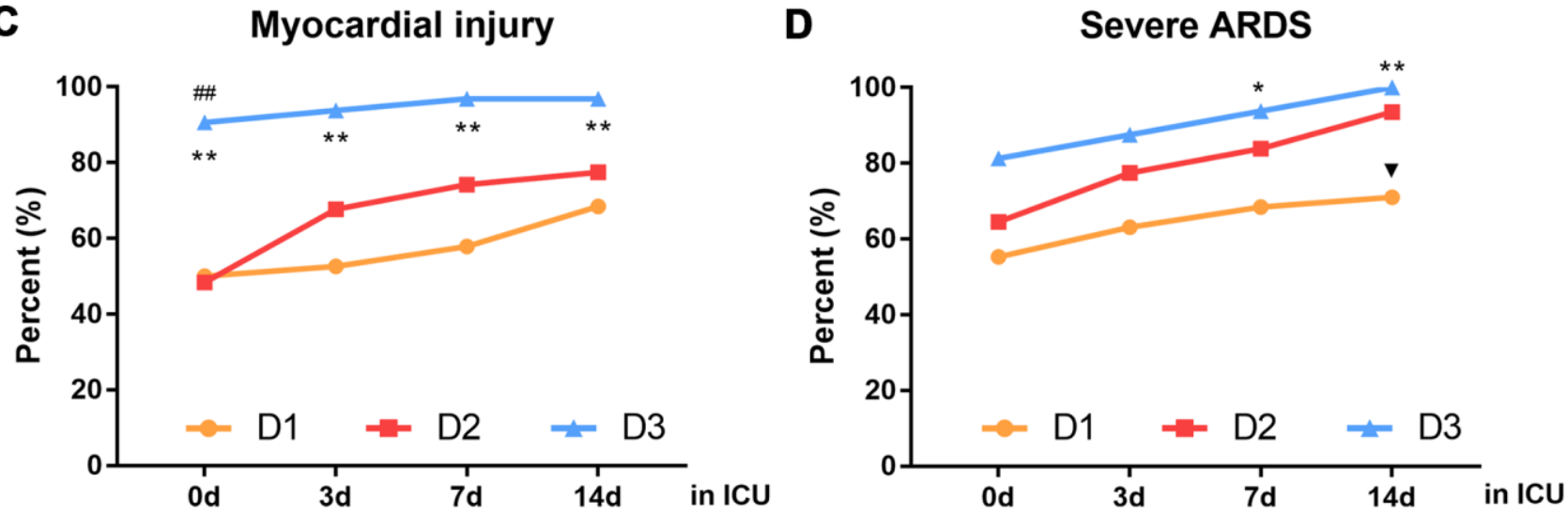

F DIC(ISTH criteria)

E

Thrombocytopenia

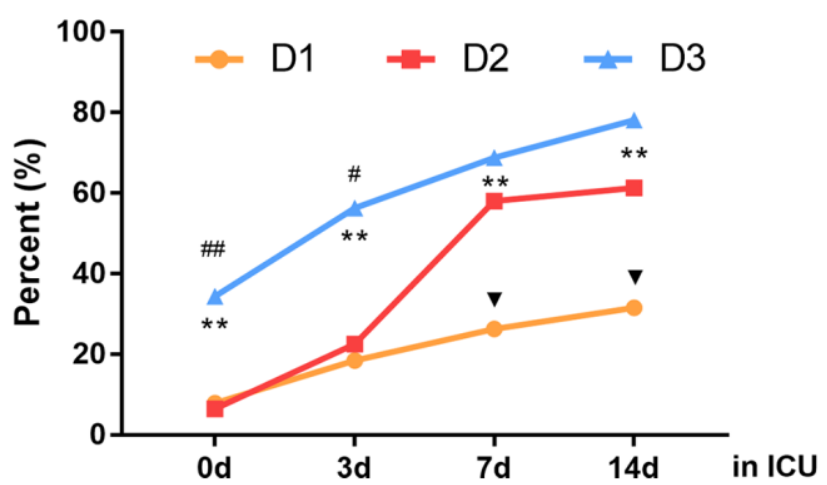

F DIC(ISTH criteria)

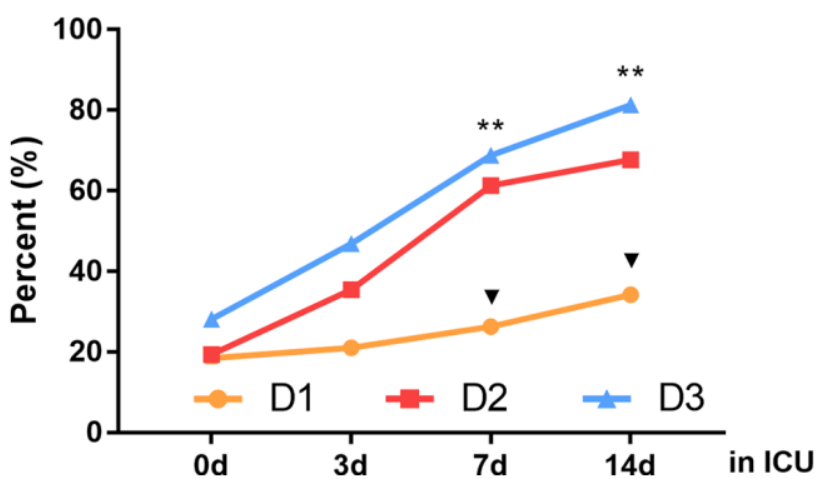

Figure 3. Dynamic changes in organ function in patients with different D-dimer levels within 14 days after ICU admission. (A) liver injury (B) kidney injury (C) myocardial injury (D) severe ARDS (E) thrombocytopenia (F) DIC (ISTH criteria), D1: 1.5 $\leq$ D-dimer $<10 \mu \mathrm{g} / \mathrm{mL}$, D2: $10 \leq \mathrm{D}$-dimer $<40 \mu \mathrm{g} / \mathrm{mL}$, D3: D-dimer $\geq 40 \mu \mathrm{g} / \mathrm{mL}$. ${ }^{\nabla} \mathrm{P}<0.05$ with D1 group vs. D2 group, ${ }^{\# P}<0.05,{ }^{\#} \mathrm{P}<0.01$ with D2 group vs. D3 group, ${ }^{*} \mathrm{P}<0.05,{ }^{*} \mathrm{P}<0.01$ with $\mathrm{D} 1$ group vs. D3 group. ARDS: acute respiratory distress syndrome, DIC: disseminated intravascular coagulation, ISTH: international society of thrombosis and hemostasis. 
count $(\mathrm{P}=0.003)$, there was no significant difference in any other parameter between the two groups, at the time of ICU admission (Figure 5B-5H). At 1-3 days after ICU admission, the levels of inflammation-related markers such as CRP $(\mathrm{P}=0.018)$, procalcitonin $(\mathrm{P}=0.004)$ and lactate dehydrogenase $(\mathrm{P}=0.026)$, were significantly different between the two groups (Figure 5B-5H). At 4-7 days after ICU admission, there were significant differences between the two groups in the levels of inflammation-related markers such as lymphocyte count $(\mathrm{P}=0.029)$, IL-6 $(\mathrm{P}=0.008)$ and ferritin $(\mathrm{P}=0.026)$ (Figure $5 \mathrm{D}-5 \mathrm{G})$, as well as in the levels of lipid metabolism-related markers such as lipoprotein (low-density lipoprotein, $\mathrm{P}=0.031$; highdensity lipoprotein, $\mathrm{P}=0.001)$, cholinesterase $(\mathrm{P}=0.007)$, cholesterol $(\mathrm{P}=0.005)$, apolipoprotein (apolipoprotein $\mathrm{A}, \mathrm{P}=0.001$; apolipoprotein $\mathrm{B}, \mathrm{P}=0.035$ ) (Figure 6).

\section{DISCUSSION}

Coagulation dysfunction is common in critically ill patients with COVID-19 [2]. Autopsy results have shown thrombosis in the lungs of patients with COVID19 , as well as in the heart, liver and kidneys $[6,7,12$, 13]. Notably, some patients develop thrombosis despite preventive anticoagulation therapy [8]. COVID-19related coagulation dysfunction is distinct from DIC and thrombotic microangiopathy; it is a unique syndrome [14]. Increasing levels of inflammatory factors in the circulation, as well as the activation of a large number of platelets and the destruction of vascular endothelial cells lead to blood stasis and hypercoagulability. Together, these effects cause extensive intravascular and microvascular thrombosis [15]. Accordingly, secondary fibrin dissolution is enhanced, which
A

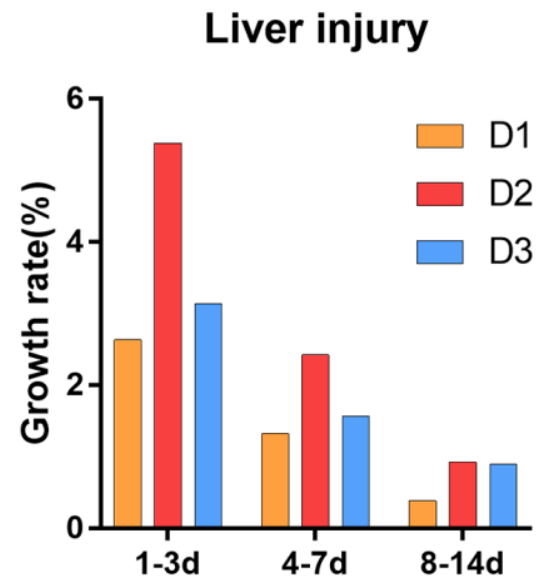

D

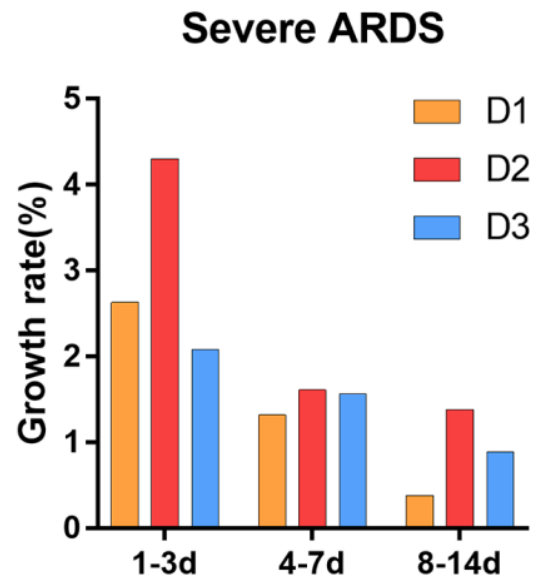

B

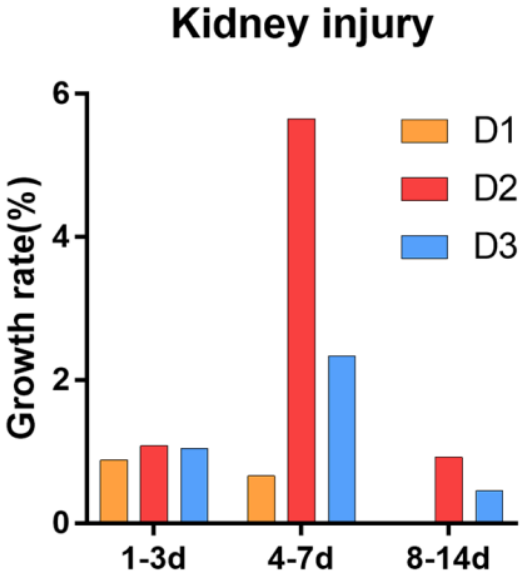

E
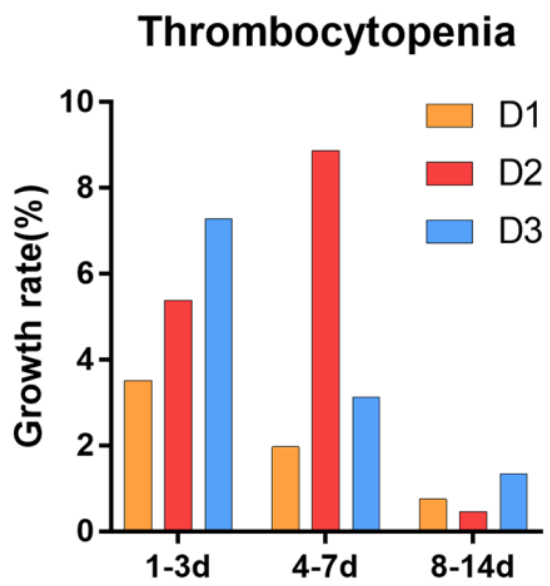

C

Myocardial injury

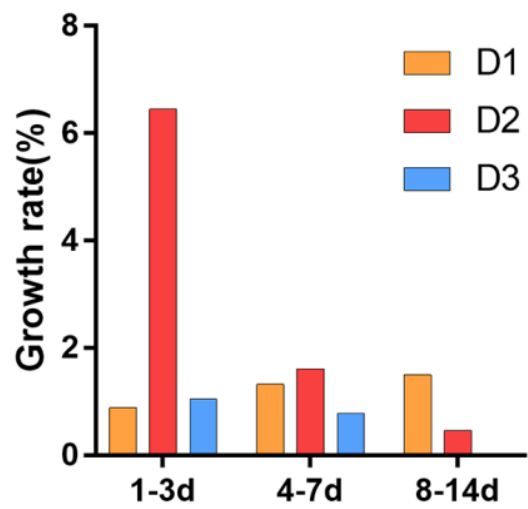

$\mathbf{F}$
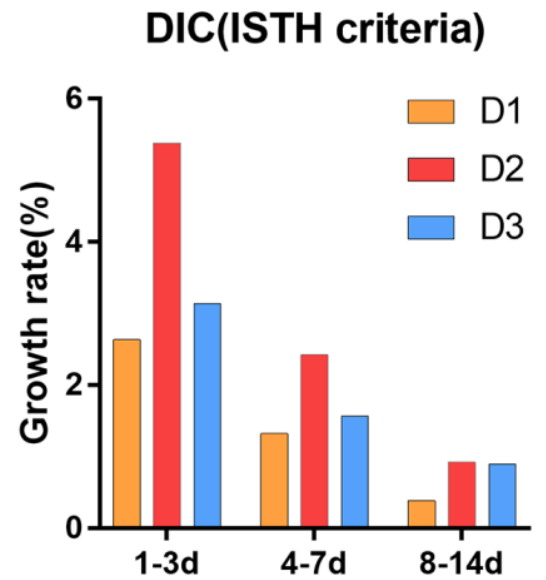

Figure 4. Growth rate of the number of patients with organ dysfunction after ICU admission. (A) liver injury (B) kidney injury (C) myocardial injury (D) severe ARDS (E) thrombocytopenia (F) DIC (ISTH criteria). D1: 1.5 $\leq \mathrm{D}$-dimer<10 $\mu \mathrm{g} / \mathrm{mL}, \mathrm{D2}$ : $10 \leq \mathrm{D}-\mathrm{dimer}<40 \mu \mathrm{g} / \mathrm{mL}, \mathrm{D} 3$ : Ddimer $\geq 40 \mu \mathrm{g} / \mathrm{mL}$. ARDS: acute respiratory distress syndrome, DIC: disseminated intravascular coagulation, ISTH: international society of thrombosis and hemostasis. 
ultimately leads to elevated levels of fibrin degradation products such as D-dimer [16]. From this perspective, the elevated D-dimer level in patients with COVID-19 is non-specific. However, considering the extensive intravascular thrombosis and DIC in these patients, an elevated D-dimer level may be informative regarding disease assessment, clinical diagnosis, and treatment selection.

An elevated D-dimer level at admission was associated with higher hospital mortality in patients with COVID19 in Wuhan [10]. In our study, because of the large number of critically ill patients in the early stage of the epidemic, some of the patients had an extremely high D-dimer level. In particular, $39.9 \%$ of the patients had a D-dimer level $>10 \mu \mathrm{g} / \mathrm{mL}$, while $20 \%$ had a D-dimer level $>40 \mu \mathrm{g} / \mathrm{mL}$. Notably, few studies have included patients with such high levels of D-dimer. An autopsy study of patients with COVID-19 from China, including those who underwent systematic autopsy $(n=37$ patients) and those who underwent percutaneous multiple organ biopsy (i.e., "minimally invasive autopsy", $\mathrm{n}=54$ ), revealed that the main cause of COVID-19-related death was multiple organ dysfunction syndrome, especially ARDS. Infection with severe acute respiratory syndrome coronavirus 2 can cause varying degrees of acute injury to multiple organs. This results in multiple organ dysfunction syndrome, in which lesions within the lung, heart, kidney and liver have serious consequences [17]. Further analysis showed that patients with D-dimer levels of $1.5-10 \mu \mathrm{g} / \mathrm{mL}$ and those with D-dimer levels of $10-40 \mu \mathrm{g} / \mathrm{mL}$ had similar disease severity (in terms of liver injury, kidney injury, myocardial injury, severe ARDS, thrombocytopenia, and DIC). Moreover, survival analysis revealed no difference in 7-day mortality rate between the two groups. However, the 14-day mortality rate was significantly higher in patients with a D-dimer level of $10-40 \mu \mathrm{g} / \mathrm{mL}$ than in those with a level of $1.5-10 \mu \mathrm{g} / \mathrm{ml}$. These findings imply that the patients with a D-dimer level of $10-40 \mu \mathrm{g} / \mathrm{mL}$ may experience rapid progression of disease with organ injury as the main manifestation 7 days after ICU admission.

There is increasing evidence that severe COVID-19 reflects a confluence of vascular dysfunction, coagulation dysfunction, and dysregulated inflammation [18]. Our analysis of patients with D-dimer levels of 1040 and $1.5-10 \mu \mathrm{g} / \mathrm{ml}$ revealed differences in the levels of inflammation markers (e.g., CRP, procalcitonin and lactate dehydrogenase) at 1-3 days after ICU admission,
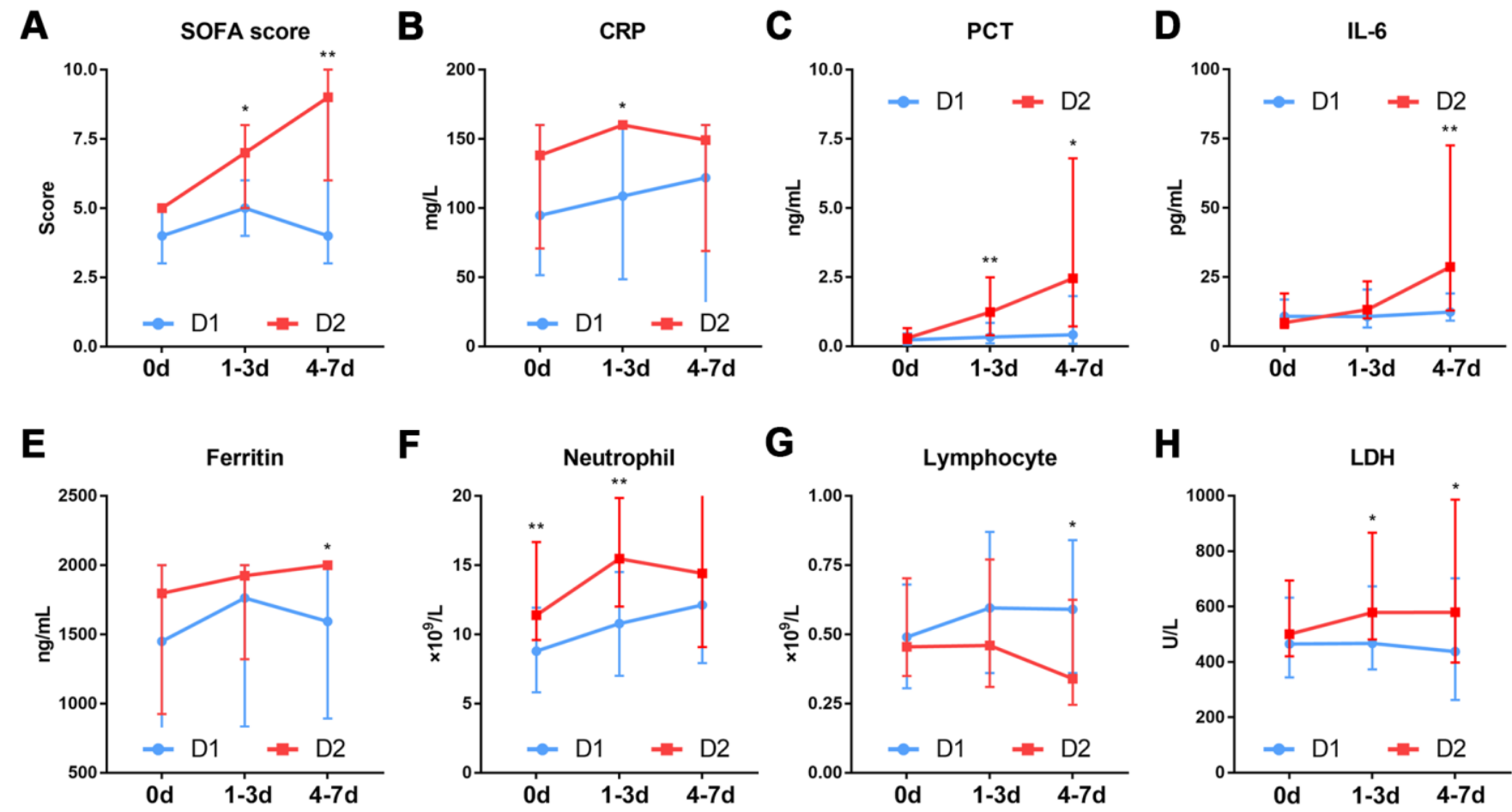

Figure 5. Dynamic changes in the SOFA score and inflammation markers in patients with different D-dimer levels. (A) SOFA

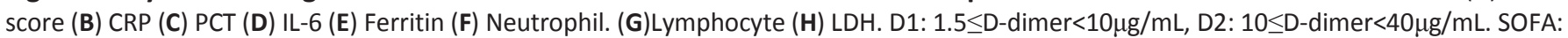
sequential organ failure assessment, CRP: c-reactive protein, PCT: procalcitonin, IL-6: Interleukin-6, LDH: Lactate dehydrogenase. ${ }^{*} \mathrm{P}<0.05$, $* * \mathrm{P}<0.01$ with $\mathrm{D} 1$ group vs. D2 group. 
whereas the IL-6 level, ferritin level and lymphocyte count were differed at 4-7 days after ICU admission. The association between coagulation and inflammation is presumed to result from crosstalk [19, 20]. During an inflammatory reaction, the secreted inflammatory mediators trigger blood coagulation and may cause blood coagulation disorders [21]. Some key components of the coagulation system can promote inflammation by direct and indirect mechanisms, according to their effects on tissue factor and fibrinogen, for example. These components of the coagulation process also have multiple roles in tissue damage and inflammation [20, 22]. For patients with a D-dimer level of $10-40 \mu \mathrm{g} / \mathrm{ml}$, early organ protection and anti-inflammatory treatment within 4-7 days after ICU admission may be beneficial. In addition, our multivariate Cox regression analysis showed the that lipids such as apolipoprotein A and B were independent risk factors for death. A recent proteomic and metabolomic profiling analysis of serum samples from patients with COVID-19 revealed that more than 100 types of amino acids and lipids were significantly reduced in serum samples from patients with severe COVID-19, which was presumably related to their consumption during rapid viral replication [23]. Similarly, we found significant differences in lipids and their metabolites between our D1 and D2 groups at 4-7 days after ICU admission. Changes in lipid metabolism also reflect changes in systemic inflammation in critically ill patients [24-26]. Therefore, the progression of organ injuries in patients with a D-dimer level of 10$40 \mu \mathrm{g} / \mathrm{ml}$ within 4-7 days after ICU admission may be related to a worsening of the inflammatory state during this period. As noted above, early organ protection and anti-inflammatory treatment may be beneficial to these patients. However, these findings should be confirmed in independent clinical studies. Our results revealed that the D-dimer level can be used to predict the prognosis of critically ill patients with COVID-19, to promote rational allocation of medical resources, and provide some guidance for the selection of drugs for these
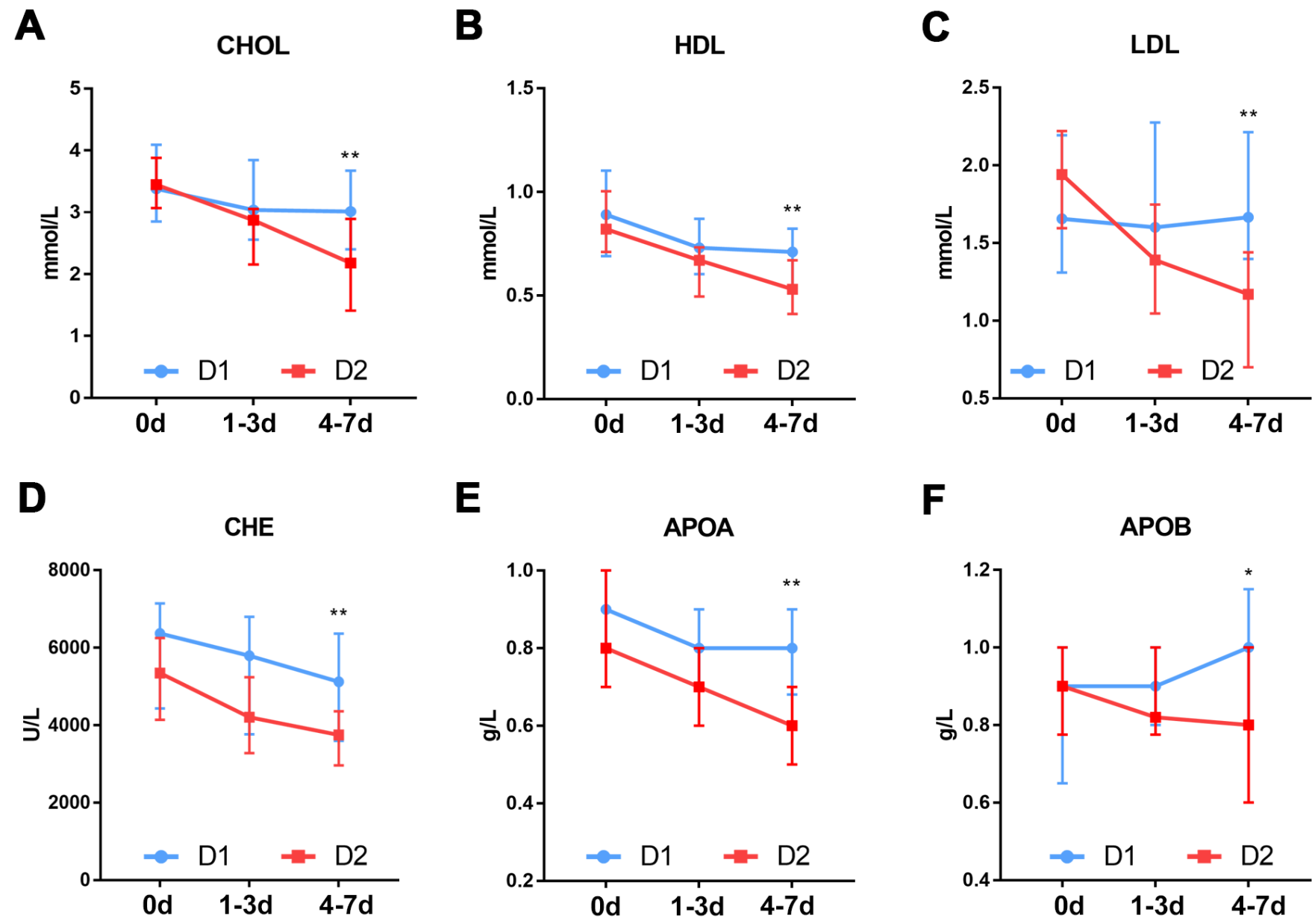

Figure 6. Dynamic changes in lipid metabolism markers in patients with different D-dimer levels. (A) CHOL (B) HDL (C) LDL (D)

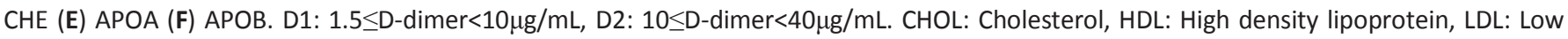
density lipoprotein, $\mathrm{CHE}$ : Cholinesterase, APOA: Apolipoprotein A, APOB: Apolipoprotein $\mathrm{B}$. ${ }^{*} \mathrm{P}<0.05,{ }^{*} \mathrm{P}<0.01$ with $\mathrm{D} 1$ group vs. $\mathrm{D} 2$ group. 
critically ill patients. Importantly, early intervention for these patients may prevent organ dysfunction.

\section{CONCLUSIONS}

An elevated D-dimer level is common among critically ill ICU patients with COVID-19. Elevated D-dimer levels, especially to $10-40 \mu \mathrm{g} / \mathrm{mL}$, are associated with a higher 14-day mortality rate in the ICU, and with the occurrence and progression of organ dysfunction in critically ill patients with COVID-19. Notably, this may be related to the secondary inflammatory state that occurs within 4-7 days after ICU admission.

\section{MATERIALS AND METHODS}

\section{Study design and data collection}

This study included 158 patients ( $\geq 18$ years of age) with confirmed COVID-19 who were admitted to ICUs in Jinyintan Hospital (a designated hospital for patients with COVID-19 in Wuhan, China) between January 20, 2020, and February 26, 2020. All patients were diagnosed with COVID-19 (severe and critical type) in accordance with the World Health Organization interim guidance and Chinese guidelines for COVID-19 management (version 7.0) [27, 28]. Epidemiological data, clinical findings, laboratory test results, and clinical records were obtained from the electronic medical record system. All data were collected by two researchers and then reviewed and confirmed by the authors of this study. The primary clinical outcome, all-cause death was monitored until March 4, 2020 (i.e., the final follow-up). This study was approved by the Research Ethics Commission of Jinyintan Hospital (KY-2020-56.01).

\section{Laboratory procedures}

The clinical laboratory of Jinyintan Hospital detected severe acute respiratory syndrome coronavirus 2 nucleic acid using the real-time reverse transcriptase polymerase chain reaction assay as described previously [29]. All laboratory data collected within 14 days after ICU admission were included in the analysis. Laboratory analyses included complete blood count, coagulation function parameters (e.g., D-dimer, fibrinogen, prothrombin time, prothrombin activity, thromboplastin time, Activated partial thromboplastin time, fibrin degradation products, and antithrombin III, inflammation markers (e.g., interleukin [IL]-6, serum ferritin, Creactive protein [CRP], procalcitonin, and lactate dehydrogenase), and various other assessments (liver function, renal function, electrolytes and myocardial enzymes). All clinical laboratory data were generated by the clinical laboratory of Jinyintan Hospital.

\section{Definition}

COVID-19 severity was defined on the basis of the Chinese guidelines for COVID-19 management (version 7.0) [28]. Disseminated intravascular coagulation (DIC) was defined in accordance with the criteria established by the International Society of Thrombosis and Hemostasis [30]. The Berlin definition of acute respiratory distress syndrome (ARDS) was used [31]. Acute kidney injury, liver injury and cardiac injury were defined in accordance with a previous study [32].

\section{Statistical analysis}

Continuous data were compared using the MannWhitney U-test or Kruskal-Wallis test and are presented as the median (interquartile range). Categorical data were compared using the chi-square test or Fisher's exact test, and are presented as counts. Univariate Cox regression analysis was used to screen potential predictors. Considering collinearity between variables, multivariate regression ultimately included age, gender, the Sequential Organ Failure Assessment (SOFA) score, D-dimer level, hypersensitive sensitive troponin I, white blood cell count, and levels of lymphocytes, C-reactive protein, lactate dehydrogenase, apolipoprotein A, and apolipoprotein B. Spearman rank correlation analysis was used to explore the association between D-dimer subgroup and clinical characteristics. Kaplan-Meier analysis was used to evaluate the cumulative mortality of patients with different D-dimer levels in the ICU. SPSS 23.0 and GraphPad Prism 7.0 were used for the analyses. $\mathrm{P}<0.05$ was considered statistically significant.

\section{AUTHOR CONTRIBUTIONS}

XZ, WZ, LS, JRS and MZ had the idea for and designed the study, WZ wrote the main manuscript text, JRS analyzed the data, DYZ, LJ, BS, LK and YZ collected the data, XZ, YSY and DYZ revised the manuscript and gave final approval for the version to be published.

\section{ACKNOWLEDGMENTS}

We are grateful to Shenghu Gong for his great support to this work for data extraction.

\section{CONFLICTS OF INTEREST}

The authors declare that they have no conflicts of interest. 


\section{FUNDING}

The work was supported by Major Projects of National Science and Technology on New Drug Creation and Development (2020ZX09201001) and Zhejiang Province Key R\&D Plan Emergency Tackling Project (2020C03123).

\section{REFERENCES}

1. Bhatraju PK, Ghassemieh BJ, Nichols M, Kim R, Jerome KR, Nalla AK, Greninger AL, Pipavath S, Wurfel MM, Evans L, Kritek PA, West TE, Luks A, et al. Covid-19 in critically ill patients in the Seattle region - case series. N Engl J Med. 2020; 382:2012-22. https://doi.org/10.1056/NEJMoa2004500 PMID:32227758

2. Tang N, Li D, Wang X, Sun Z. Abnormal coagulation parameters are associated with poor prognosis in patients with novel coronavirus pneumonia. J Thromb Haemost. 2020; 18:844-47.

https://doi.org/10.1111/jth.14768

PMID:32073213

3. Li T, Lu H, Zhang W. Clinical observation and management of COVID-19 patients. Emerg Microbes Infect. 2020; 9:687-90.

https://doi.org/10.1080/22221751.2020.1741327 PMID:32208840

4. Tang N, Bai H, Chen X, Gong J, Li D, Sun Z. Anticoagulant treatment is associated with decreased mortality in severe coronavirus disease 2019 patients with coagulopathy. J Thromb Haemost. 2020; 18:1094-99. https://doi.org/10.1111/ith.14817 PMID:32220112

5. Helms J, Tacquard C, Severac F, Leonard-Lorant I, Ohana M, Delabranche X, Merdji H, Clere-Jehl R, Schenck M, Fagot Gandet F, Fafi-Kremer S, Castelain V, Schneider F, et al, and CRICS TRIGGERSEP Group (Clinical Research in Intensive Care and Sepsis Trial Group for Global Evaluation and Research in Sepsis). High risk of thrombosis in patients with severe SARSCoV-2 infection: a multicenter prospective cohort study. Intensive Care Med. 2020; 46:1089-98. https://doi.org/10.1007/s00134-020-06062-x PMID: $\underline{32367170}$

6. Ackermann $M$, Verleden $S E$, Kuehnel $M$, Haverich $A$, Welte $T$, Laenger $F$, Vanstapel A, Werlein C, Stark H, Tzankov A, Li WW, Li VW, Mentzer SJ, Jonigk D. Pulmonary vascular endothelialitis, thrombosis, and angiogenesis in covid-19. N Engl J Med. 2020; 383:120-28.

https://doi.org/10.1056/NEJMoa2015432 PMID:32437596
7. Wichmann $D$, Sperhake JP, Lütgehetmann $M$, Steurer S, Edler C, Heinemann A, Heinrich F, Mushumba $H$, Kniep I, Schröder AS, Burdelski C, de Heer G, Nierhaus $A$, et al. Autopsy findings and venous thromboembolism in patients with COVID-19: a prospective cohort study. Ann Intern Med. 2020; 173:268-77. https://doi.org/10.7326/M20-2003 PMID:32374815

8. Lax SF, Skok K, Zechner P, Kessler HH, Kaufmann N, Koelblinger C, Vander K, Bargfrieder $U$, Trauner M. Pulmonary arterial thrombosis in COVID-19 with fatal outcome : results from a prospective, single-center, clinicopathologic case series. Ann Intern Med. 2020; 173:350-61. https://doi.org/10.7326/M20-2566 PMID:32422076

9. Levi $\mathrm{M}$, Thachil J, Iba $\mathrm{T}$, Levy JH. Coagulation abnormalities and thrombosis in patients with COVID19. Lancet Haematol. 2020; 7:e438-40. https://doi.org/10.1016/S2352-3026(20)30145-9 PMID: $\underline{2407672}$

10. Zhou F, Yu T, Du R, Fan G, Liu Y, Liu Z, Xiang J, Wang Y, Song B, Gu X, Guan L, Wei Y, Li H, et al. Clinical course and risk factors for mortality of adult inpatients with COVID-19 in Wuhan, China: a retrospective cohort study. Lancet. 2020; 395:1054-62. https://doi.org/10.1016/S0140-6736(20)30566-3 PMID: $\underline{2171076}$

11. Li $Y$, Zhao K, Wei $H$, Chen W, Wang W, Jia L, Liu $Q$, Zhang J, Shan T, Peng Z, Liu Y, Yan X. Dynamic relationship between D-dimer and COVID-19 severity. Br J Haematol. 2020; 190:e24-27. https://doi.org/10.1111/bjh.16811 PMID:32420615

12. Harenberg J, Favaloro E. COVID-19: progression of disease and intravascular coagulation - present status and future perspectives. Clin Chem Lab Med. 2020; 58:1029-36. https://doi.org/10.1515/cclm-2020-0502 PMID: $\underline{32406381}$

13. Menter T, Haslbauer JD, Nienhold R, Savic S, Hopfer H, Deigendesch N, Frank S, Turek D, Willi N, Pargger $\mathrm{H}$, Bassetti S, Leuppi JD, Cathomas G, et al. Postmortem examination of COVID-19 patients reveals diffuse alveolar damage with severe capillary congestion and variegated findings in lungs and other organs suggesting vascular dysfunction. Histopathology. 2020; 77:198-209.

https://doi.org/10.1111/his.14134 PMID:32364264

14. Giannis D, Ziogas IA, Gianni P. Coagulation disorders in coronavirus infected patients: COVID-19, SARS-CoV-1, MERS-CoV and lessons from the past. J Clin Virol. 2020; 127:104362. 
https://doi.org/10.1016/i.jcv.2020.104362 PMID:32305883

15. Wang J, Saguner AM, An J, Ning Y, Yan Y, Li G. Dysfunctional coagulation in COVID-19: from cell to bedside. Adv Ther. 2020; 37:3033-39. https://doi.org/10.1007/s12325-020-01399-7 PMID: $\underline{32504450}$

16. Lippi G, Favaloro EJ. D-dimer is associated with severity of coronavirus disease 2019: a pooled analysis. Thromb Haemost. 2020; 120:876-78. https://doi.org/10.1055/s-0040-1709650 PMID:32246450

17. Bian XW, and The COVID-19 Pathology Team. Autopsy of COVID-19 victims in China. National Science Review. 2020; 7:1414-18.

https://doi.org/10.1093/nsr/nwaa123

18. Leisman $\mathrm{DE}$, Deutschman CS, Legrand M. Facing COVID-19 in the ICU: vascular dysfunction, thrombosis, and dysregulated inflammation. Intensive Care Med. 2020; 46:1105-08.

https://doi.org/10.1007/s00134-020-06059-6

PMID:32347323

19. Burzynski LC, Clarke MC. Death is coming and the Clot thickens, as pyroptosis feeds the fire. Immunity. 2019; 50:1339-41.

https://doi.org/10.1016/j.immuni.2019.05.015 PMID:31216455

20. Luyendyk JP, Schoenecker JG, Flick MJ. The multifaceted role of fibrinogen in tissue injury and inflammation. Blood. 2019; 133:511-20.

https://doi.org/10.1182/blood-2018-07-818211

PMID: $\underline{30523120}$

21. Marshall JC. Inflammation, coagulopathy, and the pathogenesis of multiple organ dysfunction syndrome. Crit Care Med. 2001; 29:S99-106. https://doi.org/10.1097/00003246-200107001-00032 PMID:11445742

22. Mackman N. The many faces of tissue factor. J Thromb Haemost. 2009 (Suppl 1); 7:136-39.

https://doi.org/10.1111/j.1538-7836.2009.03368.x PMID: 19630786

23. Shen B, Yi X, Sun Y, Bi X, Du J, Zhang C, Quan S, Zhang F, Sun R, Qian L, Ge W, Liu W, Liang S, et al. Proteomic and metabolomic characterization of COVID-19 patient sera. Cell. 2020; 182:59-72.e15.

https://doi.org/10.1016/j.cell.2020.05.032 PMID:32492406

24. Golucci AP, Marson FA, Ribeiro AF, Nogueira RJ. Lipid profile associated with the systemic inflammatory response syndrome and sepsis in critically ill patients. Nutrition. 2018; 55:7-14. https://doi.org/10.1016/i.nut.2018.04.007 PMID:29960160

25. Lekkou A, Mouzaki A, Siagris D, Ravani I, Gogos CA. Serum lipid profile, cytokine production, and clinical outcome in patients with severe sepsis. J Crit Care. 2014; 29:723-27.

https://doi.org/10.1016/i.jcrc.2014.04.018 PMID:24891152

26. Ilias I, Vassiliadi DA, Theodorakopoulou M, Boutati E, Maratou E, Mitrou P, Nikitas N, Apollonatou S, Dimitriadis G, Armaganidis A, Dimopoulou I. Adipose tissue lipolysis and circulating lipids in acute and subacute critical illness: effects of shock and treatment. J Crit Care. 2014; 29:1130.e5-9.

https://doi.org/10.1016/j.jcrc.2014.06.003 PMID:25012960

27. WHO. Clinical management of severe acute respiratory infection when Novel coronavirus (nCoV) infection is suspected: interim guidance, 2020 Jan 28. 2020.

28. National Health Commission of the People's Republic of China. Chinese management guideline for COVID-19 (version 7.0). $2020 \mathrm{Feb} 19,2020$. http://www.nhc. gov.cn/yzygi/s7653p/202002/8334a8326dd94d329df3 51d7da8aefc2/files/b218cfeb1bc54639af227f922bf6b 817.pdf

29. Huang $C$, Wang $Y$, Li X, Ren L, Zhao J, Hu Y, Zhang L, Fan G, Xu J, Gu X, Cheng Z, Yu T, Xia J, et al. Clinical features of patients infected with 2019 novel coronavirus in Wuhan, China. Lancet. 2020; 395:497-506. https://doi.org/10.1016/S0140-6736(20)30183-5 PMID:31986264

30. Gando S, Levi M, Toh $\mathrm{CH}$. Disseminated intravascular coagulation. Nat Rev Dis Primers. 2016; 2:16037.

https://doi.org/10.1038/nrdp.2016.37 PMID:27250996

31. Ranieri VM, Rubenfeld GD, Thompson BT, Ferguson ND, Caldwell E, Fan E, Camporota L, Slutsky AS, and ARDS Definition Task Force. Acute respiratory distress syndrome: the berlin definition. JAMA. 2012; 307:2526-33.

https://doi.org/10.1001/jama.2012.5669 PMID:22797452

32. Wang D, Hu B, Hu C, Zhu F, Liu X, Zhang J, Wang B, Xiang $\mathrm{H}$, Cheng $\mathrm{Z}$, Xiong $\mathrm{Y}$, Zhao $\mathrm{Y}$, Li $\mathrm{Y}$, Wang $\mathrm{X}$, Peng $\mathrm{Z}$. Clinical characteristics of 138 Hospitalized patients with 2019 novel coronavirus-infected pneumonia in Wuhan, China. JAMA. 2020; 323:1061-69. https://doi.org/10.1001/jama.2020.1585 PMID: $\underline{32031570}$ 


\section{SUPPLEMENTARY MATERIALS}

\section{Supplementary Figures}

\section{Survival curves}

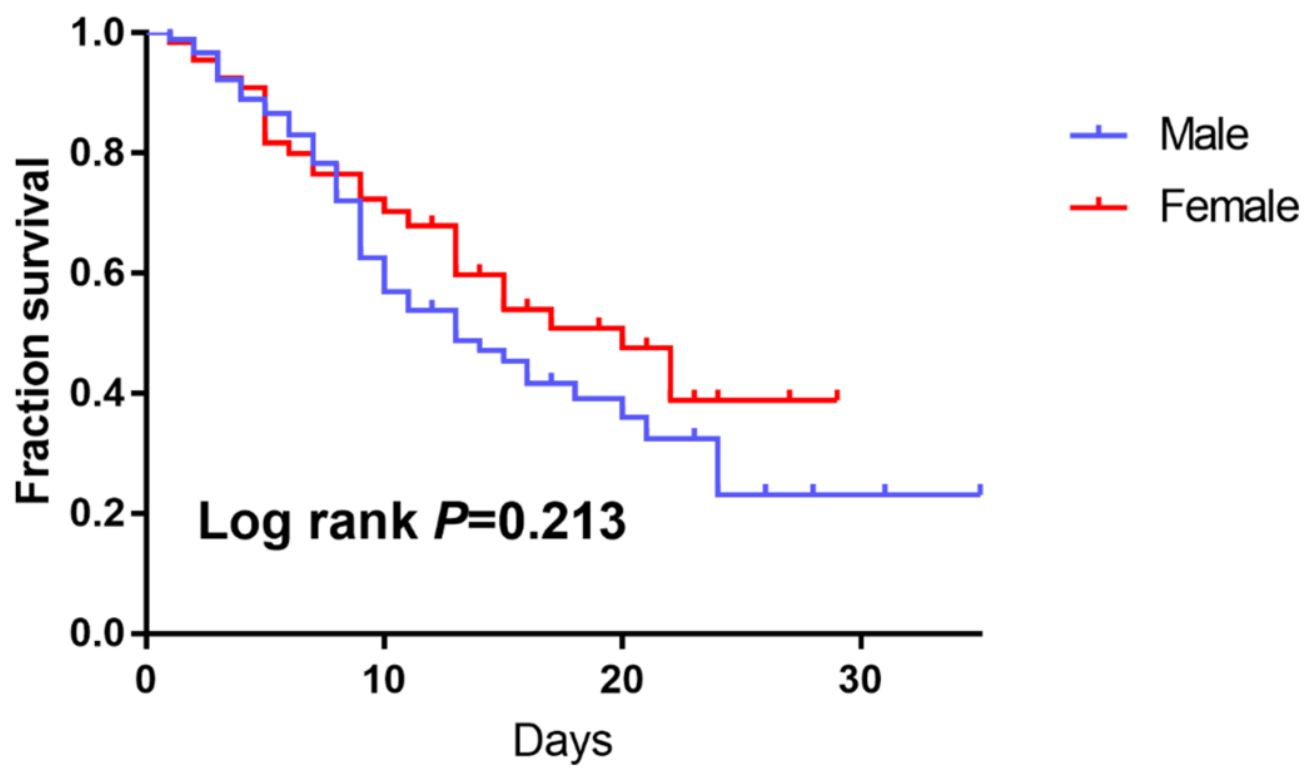

Supplementary Figure 1. Survival curves of male and female COVID-19 patients. There was no significant difference in mortality rate in ICU between male and female patients.

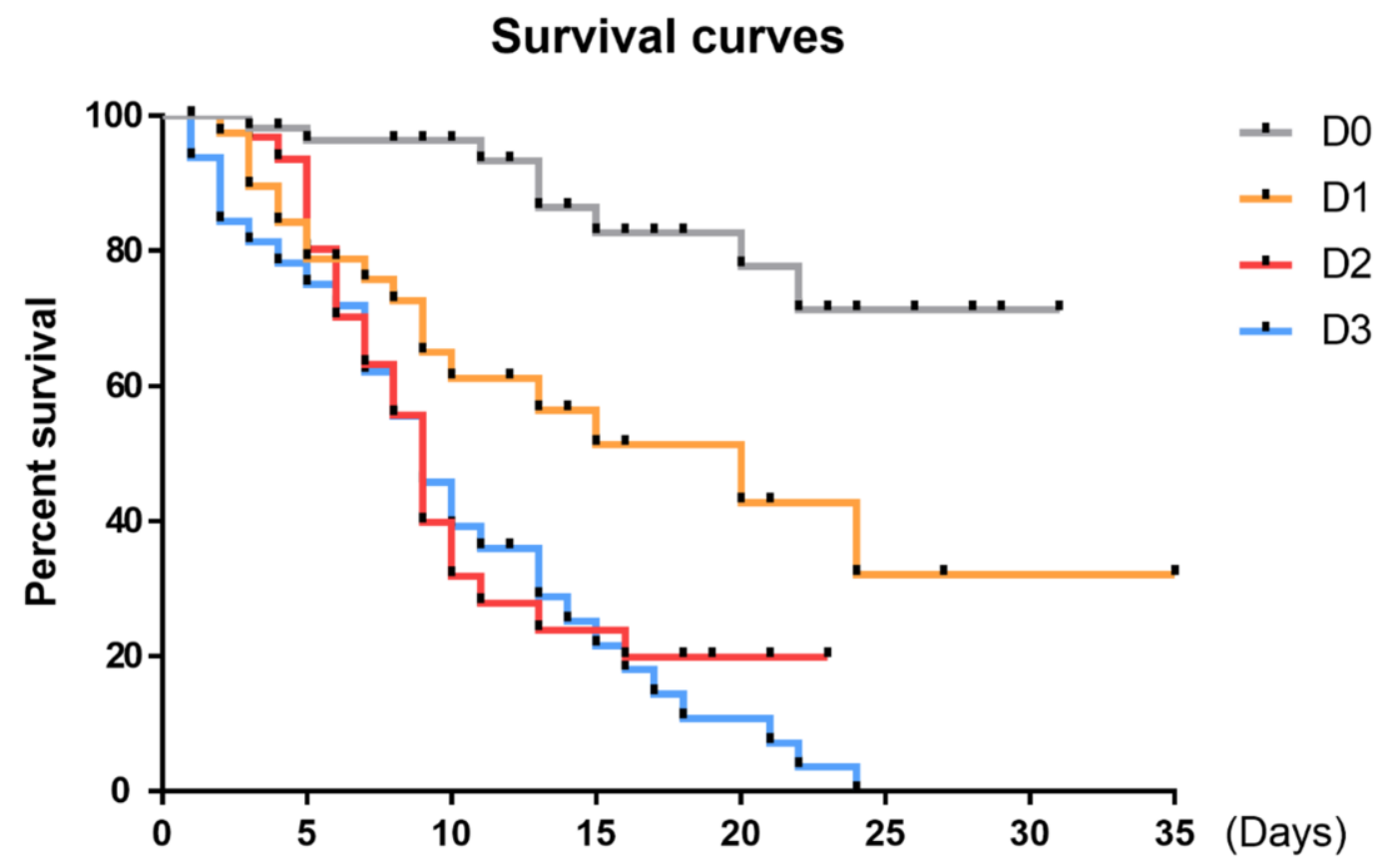

Supplementary Figure 2. Survival curve of the final mortality. D0: D-dimer $<1.5 \mu \mathrm{g} / \mathrm{mL}, \mathrm{D} 1: 1.5 \leq \mathrm{D}-\mathrm{dimer}<10 \mu \mathrm{g} / \mathrm{mL}, \mathrm{D} 2: 10 \leq \mathrm{D}$ dimer $<40 \mu \mathrm{g} / \mathrm{mL}$, D3: D-dimer $\geq 40 \mu \mathrm{g} / \mathrm{mL}$. 


\section{Supplementary Tables}

Supplementary Table 1. Spearman's rank correlation analysis for the association between D-dimer and other clinical characteristics.

\begin{tabular}{|c|c|c|c|}
\hline & $\mathbf{R}$ & $\mathbf{R 2}$ & $\mathbf{P}$ \\
\hline Age & 0.166 & 0.028 & 0.037 \\
\hline Gender, Male & -0.206 & 0.042 & 0.009 \\
\hline Anticoagulant therapy & 0.081 & 0.007 & 0.312 \\
\hline WBC $(\times 109 / \mathrm{L})$ & 0.523 & 0.274 & $<0.001$ \\
\hline Lymphocyte $(\times 109 / \mathrm{L})$ & -0.419 & 0.176 & $<0.001$ \\
\hline Neutrophil (×109/L) & 0.557 & 0.310 & $<0.001$ \\
\hline Monocyte $(\times 109 / \mathrm{L})$ & -0.010 & 0.000 & 0.898 \\
\hline $\mathrm{RBC}(\times 1012 / \mathrm{L})$ & -0.069 & 0.005 & 0.391 \\
\hline HGB $(\mathrm{g} / \mathrm{L})$ & -0.031 & 0.001 & 0.701 \\
\hline PLT $(\times 109 / \mathrm{L})$ & -0.289 & 0.084 & $<0.001$ \\
\hline PFDP $(\mu \mathrm{g} / \mathrm{mL})$ & 0.910 & 0.828 & $<0.001$ \\
\hline $\mathrm{Fbg}(\mathrm{g} / \mathrm{L})$ & -0.154 & 0.024 & 0.056 \\
\hline TT (s) & 0.081 & 0.007 & 0.315 \\
\hline PT (s) & 0.390 & 0.152 & $<0.001$ \\
\hline PTA $(\%)$ & -0.377 & 0.142 & $<0.001$ \\
\hline APTT (s) & 0.001 & 0.000 & 0.990 \\
\hline AT3 (\%) & -0.129 & 0.017 & 0.140 \\
\hline CRP (>160 mg/L) & 0.441 & 0.194 & $<0.001$ \\
\hline РCТ (>0.5 ng/mL) & 0.357 & 0.127 & $<0.001$ \\
\hline Serum ferritin (>2000 ng/mL) & 0.265 & 0.070 & $<0.001$ \\
\hline Cholesterol $(\mathrm{mmol} / \mathrm{L})$ & -0.219 & 0.048 & 0.006 \\
\hline Triglyceride $(\mathrm{mmol} / \mathrm{L})$ & 0.281 & 0.079 & $<0.001$ \\
\hline Apolipoprotein A-1 (g/L) & -0.343 & 0.118 & $<0.001$ \\
\hline Apolipoprotein B (g/L) & 0.059 & 0.003 & 0.479 \\
\hline Lipoprotein a (mg/L) & -0.085 & 0.007 & 0.306 \\
\hline $\mathrm{HDL}(\mathrm{mmol} / \mathrm{L})$ & -0.384 & 0.147 & $<0.001$ \\
\hline $\mathrm{LDL}(\mathrm{mmol} / \mathrm{L})$ & -0.210 & 0.044 & $<0.001$ \\
\hline hnTNI (pg/mL) & 0.562 & 0.316 & $<0.001$ \\
\hline $\mathrm{BNP}(\mathrm{pg} / \mathrm{mL})$ & 0.426 & 0.181 & $<0.001$ \\
\hline LDH (U/L) & 0.633 & 0.401 & $<0.001$ \\
\hline $\mathrm{HBDH}$ & 0.654 & 0.428 & $<0.001$ \\
\hline CK (U/L) & 0.135 & 0.018 & 0.094 \\
\hline CK-MB (U/L) & 0.393 & 0.154 & $<0.001$ \\
\hline $\operatorname{ALB}(g / L)$ & -0.524 & 0.275 & $<0.001$ \\
\hline ALT (U/L) & 0.227 & 0.052 & 0.004 \\
\hline AST (U/L) & 0.332 & 0.110 & $<0.001$ \\
\hline Cholinesterase (U/L) & -0.415 & 0.172 & $<0.001$ \\
\hline $\mathrm{Cr}(\mu \mathrm{mol} / \mathrm{L})$ & 0.162 & 0.026 & 0.044 \\
\hline eGFR (ml/(min*1.73m2)) & -0.131 & 0.017 & 0.112 \\
\hline Uric acid (umol/L) & -0.107 & 0.011 & 0.181 \\
\hline Cystatin-c (mg/L) & 0.265 & 0.070 & 0.001 \\
\hline DIC (ISTH criteria) & 0.314 & 0.099 & $<0.001$ \\
\hline $\mathrm{PaO} 2 / \mathrm{FiO} 2<100$ & 0.027 & 0.001 & 0.738 \\
\hline
\end{tabular}


Supplementary Table 2. Univariate and multivariate Cox regression analysis for the outcome of COVID-19 patients.

\begin{tabular}{|c|c|c|c|c|}
\hline & \multirow{2}{*}{$\begin{array}{c}\text { Univariable } \\
\text { HR }\end{array}$} & \multicolumn{3}{|c|}{ Multivariable } \\
\hline & & $\mathbf{P}$ & HR & $\mathbf{P}$ \\
\hline Age & $1.037(1.016-1.058)$ & $<0.001$ & $1.057(1.028-1.086)$ & $<0.001$ \\
\hline Gender (vs male) & $0.570(0.471-1.194)$ & 0.225 & & \\
\hline Sofa score & $1.468(1.313-1.641)$ & $<0.001$ & $1.191(1.011-1.403)$ & 0.037 \\
\hline \multicolumn{5}{|l|}{ hsTNI } \\
\hline$\leq 28$ & 1 (ref) & & & \\
\hline$>28$ & $4.996(2.963-8.426)$ & $<0.001$ & & \\
\hline \multicolumn{5}{|l|}{ D-dimer } \\
\hline$<1.5$ & 1 (ref) & & 1 (ref) & \\
\hline $1.5-10$ & $4.202(1.811-9.751)$ & 0.001 & $3.600(1.455-8.911)$ & 0.006 \\
\hline $10-40$ & $8.335(3.673-18.910)$ & $<0.001$ & $4.160(1.727-10.022)$ & 0.001 \\
\hline$>40$ & $10.016(4.570-21.950)$ & $<0.001$ & $2.732(1.077-6.927)$ & 0.034 \\
\hline WBC & $1.052(1.025-1.080)$ & $<0.001$ & & \\
\hline LYM & $0.340(0.170-0.680)$ & 0.002 & & \\
\hline IL-6 & $1.005(0.996-1.015)$ & 0.241 & & \\
\hline \multicolumn{5}{|l|}{ PCT } \\
\hline$<0.05$ & 1 (ref) & & & \\
\hline $0.05-0.5$ & $3.447(1.519-7.823)$ & 0.003 & & \\
\hline$>0.5$ & $9.716(4.300-21.950)$ & $<0.001$ & & \\
\hline \multicolumn{5}{|l|}{ Serum ferritin } \\
\hline$<1000$ & 1 (ref) & & & \\
\hline $1000-2000$ & $2.000(1.064-3.760)$ & 0.031 & & \\
\hline$>2000$ & $1.897(1.051-3.422)$ & 0.034 & & \\
\hline \multicolumn{5}{|l|}{$\mathrm{Cr}$} \\
\hline$\leq 133$ & 1 (ref) & & & \\
\hline$>133$ & $1.692(0.891-3.215)$ & 0.108 & & \\
\hline \multicolumn{5}{|l|}{ CRP } \\
\hline$\leq 160$ & 1 (ref) & & & \\
\hline$>160$ & $2.686(1.695-4.254)$ & $<0.001$ & & \\
\hline ALT & $1.0001(0.999-1.003)$ & 0.157 & & \\
\hline LDH, per 10 increase & $1.013(1.009-1.017)$ & $<0.001$ & $1.010(1.003-1.017)$ & 0.005 \\
\hline CHOL & $0.729(0.567-0.936)$ & 0.013 & & \\
\hline TC & $1.000(0.998-1.002)$ & 0.865 & & \\
\hline HDL & $0.210(0.082-0.540)$ & 0.001 & & \\
\hline LDL & $0.853(0.574-1.268)$ & 0.432 & & \\
\hline CHE, per 100 increase & $0.980(0.968-0.991)$ & 0.001 & & \\
\hline APOA & $0.075(0.023-.250)$ & $<0.001$ & $0.148(0.039-0.554)$ & 0.005 \\
\hline APOB & $0.945(0.919-0.972)$ & $<0.001$ & $0.951(0.924-0.978)$ & $<0.001$ \\
\hline
\end{tabular}


Supplementary Table 3. Abbreviation and range of normal values of laboratory results.

\begin{tabular}{|c|c|c|c|}
\hline Abbreviation & laboratory chemistries & range of normal values & unit \\
\hline D-dimer & D-dimer & $0-1.5$ & $\mathrm{ug} / \mathrm{mL}$ \\
\hline Fbg & Fibrinogen & $2-4$ & $\mathrm{~g} / \mathrm{L}$ \\
\hline TT & Thromboplastin time & $13-21$ & $\mathrm{~s}$ \\
\hline PT & Prothrombin time & $75-125$ & $\%$ \\
\hline PTA & PT activity & $10.5-13.5$ & $\mathrm{~s}$ \\
\hline FDP & Fibrin degradation product & $0-5$ & $\mathrm{ug} / \mathrm{mL}$ \\
\hline AT3 & Antithrombin III & $75-125$ & $\%$ \\
\hline INR & International Normalized Ratio & $0.8-1.2$ & - \\
\hline APTT & Activated partial TT & $21-37$ & $\mathrm{~s}$ \\
\hline IL-6 & Interleukin-6 & $0-7$ & $\mathrm{pg} / \mathrm{mL}$ \\
\hline PCT & Procalcitonin & $<0.5 \mathrm{ng} / \mathrm{ml}$ & $\mathrm{ng} / \mathrm{mL}$ \\
\hline ESR & Erythrocyte Sedimentation Rate & $0-20$ & $\mathrm{~mm} / \mathrm{h}$ \\
\hline Ferritin & Ferritin & 21.8-274.66 & $\mathrm{ng} / \mathrm{mL}$ \\
\hline CRP & C-reactive protein & $0-6$ & $\mathrm{mg} / \mathrm{L}$ \\
\hline BNP & B-type natriuretic peptide & $0-100$ & $\mathrm{pg} / \mathrm{mL}$ \\
\hline hsTnI & Hypersensitive sensitive troponin I & $0-28$ & $\mathrm{pg} / \mathrm{mL}$ \\
\hline Myoglobin & Myoglobin & $0.0-146.9$ & $\mathrm{ng} / \mathrm{mL}$ \\
\hline $\mathrm{CK}$ & Creatine kinase & $50-310$ & $\mathrm{U} / \mathrm{L}$ \\
\hline CK-MB & Creatine kinase-MB & $0-24$ & $\mathrm{U} / \mathrm{L}$ \\
\hline AMY & Amylase & $35-135$ & $\mathrm{U} / \mathrm{L}$ \\
\hline LPS & Lipase & 8-78 & $\mathrm{U} / \mathrm{L}$ \\
\hline $\mathrm{CHE}$ & Cholinesterase & $5000-12000$ & $\mathrm{U} / \mathrm{L}$ \\
\hline DBIL & Direct Bilirubin & $0-8$ & $\mathrm{umol} / \mathrm{L}$ \\
\hline IBIL & Indirect bilirubin & $0-13$ & $\mu \mathrm{mol} / \mathrm{L}$ \\
\hline GLOB & Globulin & $20-40$ & $\mathrm{~g} / \mathrm{L}$ \\
\hline ALB & Albumin & $40-55$ & $\mathrm{~g} / \mathrm{L}$ \\
\hline ALT & Alanine aminotransferase & $7-40$ & $\mathrm{U} / \mathrm{L}$ \\
\hline AST & Aspartate aminotransferase & $13-35$ & $\mathrm{U} / \mathrm{L}$ \\
\hline TBIL & Totalbilirubin & $0-21$ & $\mu \mathrm{mol} / \mathrm{L}$ \\
\hline CREA & Creatinine & $57-111$ & $\mathrm{umol} / \mathrm{L}$ \\
\hline UREA & Urea & $3.1-9.5$ & $\mathrm{mmol} / \mathrm{L}$ \\
\hline eGFR & estimated Glomerularfiltrationrate & $>90$ & $\mathrm{ml} /\left(\min * 1.73 \mathrm{M}^{\wedge} 2\right)$ \\
\hline $\mathrm{Ca}$ & Calcium & $2.11-2.52$ & $\mathrm{mmol} / \mathrm{L}$ \\
\hline $\mathrm{Cl}$ & Chloridion & $96-108$ & $\mathrm{mmol} / \mathrm{L}$ \\
\hline $\mathrm{K}$ & Kalium & $3.5-5.3$ & $\mathrm{mmol} / \mathrm{L}$ \\
\hline $\mathrm{Na}$ & Sodion & $137-147$ & $\mathrm{mmol} / \mathrm{L}$ \\
\hline ALP & Alkaline phosphatase & $50-135$ & $\mathrm{U} / \mathrm{L}$ \\
\hline CHOL & Cholesterol & $3.3-5.2$ & $\mathrm{mmol} / \mathrm{L}$ \\
\hline GGT & Gamma-glutamyl transpeptidase & $7-45$ & $\mathrm{U} / \mathrm{L}$ \\
\hline UA & Uric acid & $208-428$ & $\mathrm{umol} / \mathrm{L}$ \\
\hline GLU & Glucose & $3.9-6.1$ & $\mathrm{mmol} / \mathrm{L}$ \\
\hline $5-\mathrm{NT}$ & 5'-nucleotidase & $0-10$ & $\mathrm{U} / \mathrm{L}$ \\
\hline AFU-L & alpha-L-fucosidase & $0-40$ & $\mathrm{U} / \mathrm{L}$ \\
\hline APOA & Apolipoprotein A & $1.0-1.60$ & $\mathrm{~g} / \mathrm{L}$ \\
\hline APOB & Apolipoprotein B & $0.6-1.1$ & $\mathrm{~g} / \mathrm{L}$ \\
\hline CYSC & Cystatin C & $0.6-1.55$ & $\mathrm{mg} / \mathrm{L}$ \\
\hline HDL & High density lipoprotein & $1.16-1.42$ & $\mathrm{mmol} / \mathrm{L}$ \\
\hline LDL & Low density lipoprotein & $2.1-3.37$ & $\mathrm{mmol} / \mathrm{L}$ \\
\hline $\mathrm{LPa}$ & Lipoprotein a & $0-300$ & $\mathrm{mg} / \mathrm{L}$ \\
\hline PA & Prealbumin & $180-350$ & $\mathrm{mg} / \mathrm{L}$ \\
\hline RBP & Retinol binding protein & $25-70$ & $\mathrm{ug} / \mathrm{mL}$ \\
\hline SAA & Serum amyloid protein & $0-10$ & $\mathrm{mg} / \mathrm{L}$ \\
\hline TBA & Total bile acid & $0-12$ & $\mathrm{umol} / \mathrm{L}$ \\
\hline TG & Triglycerides & $0.51-1.70$ & $\mathrm{mmol} / \mathrm{L}$ \\
\hline
\end{tabular}




\begin{tabular}{|c|c|c|c|}
\hline aHBDH & $\alpha$-Hydroxybutyrate dehydrogenase & $72-182$ & $\mathrm{U} / \mathrm{L}$ \\
\hline LDH & Lactate dehydrogenase & $120-250$ & $\mathrm{U} / \mathrm{L}$ \\
\hline BAS\# & Basophilic granulocyte (absolute value) & $0-0.06$ & $10^{\wedge} 9 / \mathrm{L}$ \\
\hline BAS $\%$ & Basophilic granulocyte (percentage) & $0-1$ & $\%$ \\
\hline EOS\# & $\begin{array}{l}\text { Eosinophilic granulocyte (absolute } \\
\text { value) }\end{array}$ & $0.02-0.52$ & $10^{\wedge} 9 / \mathrm{L}$ \\
\hline EOS\% & Eosinophilic granulocyte (percentage) & $0.4-8.0$ & $\%$ \\
\hline HCT & Hematokrit & $35-45$ & $\%$ \\
\hline HGB & Hemoglobin & $115-150$ & $\mathrm{~g} / \mathrm{L}$ \\
\hline LYM\# & Lymphocyte (absolute value) & $1.1-3.2$ & $10^{\wedge} 9 / \mathrm{L}$ \\
\hline LYM\% & Lymphocyte (percentage) & $20-50$ & $\%$ \\
\hline $\mathrm{MCH}$ & Mean corpuscular hemoglobin & $27-34$ & $\mathrm{pg}$ \\
\hline $\mathrm{MCHC}$ & $\begin{array}{l}\text { Mean corpusular hemoglobin } \\
\text { concerntration }\end{array}$ & 316-354 & $\mathrm{g} / \mathrm{L}$ \\
\hline $\mathrm{MCV}$ & Mean corpuscular volume & $82-100$ & $\mathrm{fL}$ \\
\hline MON\# & Monocyte (absolute value) & $0.1-0.6$ & $10^{\wedge} 9 / \mathrm{L}$ \\
\hline MON\% & Monocyte (percentage) & $3-10$ & $\%$ \\
\hline MPV & Mean platelet volume & $9-13$ & $\mathrm{fL}$ \\
\hline NEU\# & Neutrophile granulocyte (absolute value) & $1.8-6.3$ & $10^{\wedge} 9 / \mathrm{L}$ \\
\hline NEU\% & Neutrophile granulocyte (percentage) & $40-75$ & $\%$ \\
\hline PDW & Platelet distribution width & $9-17$ & $\%$ \\
\hline PLT & Platelets & $125-350$ & $10^{\wedge} 9 / \mathrm{L}$ \\
\hline $\mathrm{RBC}$ & Red blood cell & $3.8-5.1$ & $10^{\wedge} 12 / \mathrm{L}$ \\
\hline RDW-CV & $\begin{array}{c}\text { Red cell distribution width-coefficient of } \\
\text { variation }\end{array}$ & $11-16$ & $\%$ \\
\hline RDW-SD & $\begin{array}{l}\text { Red cell distribution width-Standard } \\
\text { deviation }\end{array}$ & $37-50$ & $\mathrm{fL}$ \\
\hline PLTCT & Thrombocytocrit & $0.17-0.35$ & - \\
\hline WBC & White blood cell & $3.5-9.5$ & $10^{\wedge} 9 / \mathrm{L}$ \\
\hline
\end{tabular}

